\title{
Use of gum blend in the optimization of grape molasses halva Gazi formulation with an emphasis on texture properties
}

\author{
Hassan ABHARI ${ }^{1}$, Amir Hossein ELHAMI RAD ${ }^{1,2}$, Hojjat KARAZHIYAN ${ }^{3}$, Abbas ABHARI ${ }^{4}$ \\ Received February 12, 2020; accepted October 06, 2020. \\ Delo je prispelo 12. februarja 2020, sprejeto 06. oktobra 2020.
}

Use of gum blend in the optimization of grape molasses halva Gazi formulation with an emphasis on texture properties

Abstract: Grape molasses is a traditional sweet with high nutritional value. One factor limiting the production and storage of grape molasse halva Gazi is related to the thermal sensitivity of its texture properties and decreasing its quality during storage at ambient temperature. Therefore, this study aimed to improve the texture properties of the newly formulated halva during storage at different temperatures. Different levels of gums $(0.5 \%, 1 \%$ \& $1.5 \%)$ including alginate, carrageenan, xanthan, and their blends ( $0.5 \%-0.5 \%)$ were used as additives in the formulation of halva to improve its texture during $48 \mathrm{~h}$ storage at $25^{\circ} \mathrm{C}$ and $40{ }^{\circ} \mathrm{C}$. The texture analysis tests were then performed to evaluate the firmness and fracturability of the halva. The results showed that the combination of gums, as well as using xanthan gum alone, produced an appropriate and soft texture in comparison to the control halva ( $0 \%$ gum). However, the halva containing carrageenan-alginate blends showed the softest texture. The samples containing 0.5 and $1 \%$ of alginate and xanthan as well as xanthan-alginate blend and xanthancarrageenan blend had the best texture properties during storage at $40{ }^{\circ} \mathrm{C}$.

Key words: grape molasses halva Gazi; gum; temperature stability; texture
Uporaba mešanice aditivov za optimizacijo molase iz grozdja pri pripravi halve Gazi s poudarkom na njeni teksturi

Izvleček: Molasa iz grozdja je osnovna sestavina tradicionalne slaščice Gazi halva, ki ima veliko hranilno vrednost. Eden izmed omejujočih dejavnikov pri pripravi in shranjevanju te slaščice je toplotna občutljivost molase iz grozdja, kar vpliva na njeno teksturo pri shranjevanju na sobni temperature.V raziskavi je predstavljen nov način priprave halve za shranjevanje na različnih temperaturah. Kot polnilo so bile pri pripravi halve dodane različne količine aditivov $(0,5 \%, 1 \%$ \& $1,5 \%)$ kot so alginat, karaginan, ksantan in njihove mešanice (0,5 \%-0,5 \%) za izboljšanje njene teksture pri 48 urnem shranjevanju na $25^{\circ} \mathrm{C}$ in $40^{\circ} \mathrm{C}$. Za oceno čvrstosti in lomljivosti halve so bili narejeni preiskusi njene teksture. Rezultati so pokazali, da je kombinacija polnil kot tudi uporaba samo ksantana dala primerno mehko teksturo v primerjavi s kontrolno pripravo halve brez aditivov ( $0 \%$ aditiva). Najmehkejšo teksturo je imela halva pripravljena $\mathrm{z}$ mešanico karaginana in alginata. Vzorci halve, ki so vsebovali 0,5 in $1 \%$ alginata in ksantana kot tudi tisti z mešanicami alginata in ksantana ter ksantana in karaginana so imeli najboljšo teksturo za shranjevanje na $40^{\circ} \mathrm{C}$.

Ključne besede: halva Gazi z molaso iz grozdja; aditivi; teperaturna obstojnost; tekstura

Islamic Azad University, Department of Food Science and Technology, Sabzevar Branch, Sabzevar, Iran

2 Corresponding author, e-mail: ahelhamirad@yahoo.com

3 Islamic Azad University, Torbat Heydariyeh Branch, Department of Food Science and Technology, TorbatHeydariyeh, Iran

4 Payamenoor University 193594697, Department of Agronomy, Tehran, IR, Iran 


\section{INTRODUCTION}

Grape molasses halva (kernelled halva or halva Josie), high nutritional value and delicious product, is popular in Iran, especially in Sabzevar and Torbate-Heydariyeh. It containsgrape molasses (as a natural sweetener),chubak extract, sesame, and walnut kernel (Löfgren et al., 2006).

The texture is considered as an important physical aspect affecting the acceptance of the food products. Hydrocolloids are widely used as gelling agents in food systems to preserve and/or improve the texture of the products as a texture modifier (Nussinovitch, 2003). Hydrocolloids have different functional properties influencing the process parameters, evaporated water retention, freezing rate, and growth of ice crystals, as well as chemical reactions. One factor limiting the production and storage of grape molasses halva Gazi is related to the thermal sensitivity of its texture properties and decreasing its quality during storage at ambient temperature. Preserving this halva at $25^{\circ} \mathrm{C}$ or higher temperatures shows an adverse effect on its texture; hence, this is usually produced during cold months of the year (from November to late April).Therefore, the use of heat-resistant gums such as carrageenan, alginate, and xanthan will be effective to increase its shelf life by preserving the gel structure and improving the texture of halva. For example, it was revealed that the xanthan gum is thermal resistant as it can preserve its viscosity at autoclave processing condition $\left(121^{\circ} \mathrm{C}\right.$ and pressure of $15 \mathrm{psi}$ ) (Fallah, Motamedzadegan, 2013). Movahed et al. (2014) reported that the use of xanthan gum and potato flour increased the toast texture softening and prevented from its staling. It was found that adding guar and carrageenan affected the physical and organoleptic properties of Barbari bread; as, the firmness of bread decreased by adding guar gum especially at the level of $0.5 \%$ (Qureshi et al., 2009).

In this study, various gums including xanthan, carrageenan, alginate gums and their blends were used to improve the texture of halva Gazi during storage at ambient temperature or higher.

\section{MATERIALS AND METHODS}

\subsection{MATERIALS}

All required ingredients for the preparation of halva Gazi including sesame, walnut and grape molasses were obtained from a local market in Sabzevar, Iran. The gums (xanthan, carrageenan, and alginate) were prepared from Sigma Aldridge Company.

\subsection{PREPARATION OF HALVA GAZI}

At first, the chubak extract was prepared according to the method of Keyhani et al. (2010).To prepare the halva Gazi, the chubak extract solution (10\%) was mixed with grape molasses. The mixture is then brought to the boiling temperature in a cast-iron container increased the grape molasses Brix. The boiling process was continued to achieve the desired Brix of the mixture that was determined based on observing the formed bubbles (with approximately $3 \mathrm{~mm}$ diameter). The temperature was then reduced. The mixture was stirred for about two hours to obtain the desired texture. To prepare the halva containing gum, different levels of heat-resistant gums including xanthan, carrageenan and alginate $(0.5 \%, 1 \%$, and $1.5 \%)$ and their blends (0.5\%-0.5 \%) were added to the mixture in the last $30 \mathrm{~min}$ of stirring. Finally, the sesame seeds were added and the halva was transferred into the trays or tablecloths covered with barley flour and decorated with walnut kernels before the texture hardening (Löfgren et al., 2006).The produced samples were stored at $25^{\circ} \mathrm{C}$ and $40{ }^{\circ} \mathrm{C}$ for $48 \mathrm{~h}$ before analyzing the texture properties.

\subsection{TEXTURE PROFILE ANALYSIS}

As shown in Fig. 1, the texture properties of the food can be evaluated using a device by placing food under a force through deformation, disintegration, and flowing, with a combination of mass, distance, and time (Bourne, 2009). According to Table 1, the texture analyzer probe with a mass of $4.5 \mathrm{~kg}$ was used to evaluate the halva texture properties (firmness and factorability) according to AACC 09-74. For this purpose, a specific piece of halva

Table 1: The used levels of gums in formulation of the halva

\begin{tabular}{ll}
\hline Treatment & Gum concentration (\%) \\
\hline Control (traditional) & 0.0 \\
Xanthan & 0.5 \\
& 1.0 \\
& 1.5 \\
Carrageenan & 0.5 \\
& 1.0 \\
Alginate & 1.5 \\
& 0.5 \\
Xanthan-Carrageenan & 1.0 \\
Xanthan - Alginate & 1.5 \\
Alginate-Carrageenan & $0.5-0.5$ \\
\hline
\end{tabular}




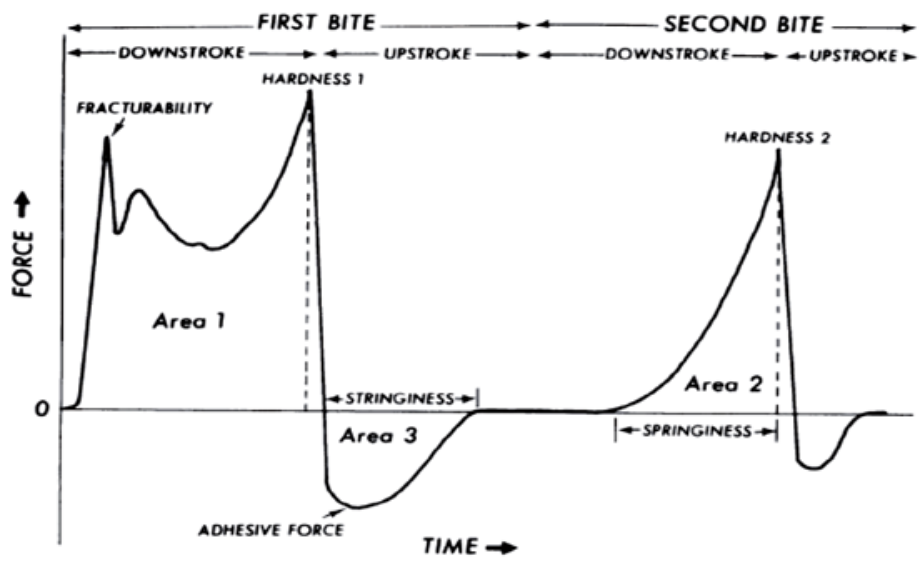

Figure 1: Texture profile analysis according to Bourn (2009)

Gazi $(25 \mathrm{~mm} \times 25 \mathrm{~mm} \times 25 \mathrm{~mm})$ was placed on the mandible of the device. The diameter and speed of the probe were $35 \mathrm{~mm}$ and $30 \mathrm{~mm} \mathrm{~min}^{-1}$. Each sample was compressed to $40 \%$ of initial height in two reciprocating cycles (two goings and two comings) and it was then decompressed (Takahashi et al., 2009).

\subsection{THE STATISTICAL ANALYSIS}

All experiments were performed in triplicate. The completely randomized factorial design was used to analyze the obtained data using SPPS 21 software. Results were submitted to analysis of variance (ANOVA) using Duncan's multiple range test with a significance level of $p<0.05$.

\section{RESULTS AND DISCUSSION}

\subsection{THE EFFECT OF CARRAGEENAN GUM ON FIRMNESS AND FRACTURABILITY OF HALVA GAZI}

Firmness represents the resistance of the sample to applied compressive forces (Szczesniak, 2002). As shown in Fig. 2 a, the firmness of halva increased as higher levels of carrageenan gum were used $(p<0.05)$. It was also observed that the firmness decreased during storage at a higher temperature $(p<0.05)$. The interaction effect of gum concentration and storage temperature was also significant $(p<0.05)$. Using $0.5 \%$ of carrageenan wasn't effective to improve the texture of the stored halva at $40{ }^{\circ} \mathrm{C}$ as there was no significant difference between the firmness of this sample and the control. The sample containing $1.5 \%$ carrageenan gum had a firmer texture than the control one during storage at $40^{\circ} \mathrm{C}$. However, this sample had very firm and undesirable texture at ambient temperature $\left(25^{\circ} \mathrm{C}\right)$.

Movahed (2014) reported that the strength of carrageenan gel decreased at the higher temperature. At about $55{ }^{\circ} \mathrm{C}$, the carrageenan gum molecules swell and its hydrogen bonds partially break down. During cooling, new hydrogen bonds are formed between the carrageenan chains causes the reforming of the gel structure. Heating at a higher temperature $\left(>80^{\circ} \mathrm{C}\right)$ produces the stronger and firmer gel that can be stable in autoclave conditions (Phillips, 2000). During heating at a higher temperature than its melting point, the irregular loops are created in the carrageenan gel structure due to thermal perturbation allowing the formation of double helixes at the coupling point resulting in the formation of a three-dimensional network (Lofgrent, 2006).

The effects of concentrations of carrageenan gum on the fracturability index of the halva Gazi texture were shown in Fig. 2. b. The fracturability or tenderness of the halva increased as higher levels of carrageenan were applied $(p<0.05)$.This factor decreased during the storage of the samples at a higher temperature $(p<$ $0.05)$.The interaction effect of these independent variables was also considerable $(p<0.05)$. Comparing the fracturability of the stored samples at $20^{\circ} \mathrm{C}$ and $40{ }^{\circ} \mathrm{C}$ revealed that the reduction in this factor was more noticeable in the halva containing $1.5 \%$ carrageen and gum. These results could be explained based on the structure of the gel network and the various chemical interactions between the hydrocolloid and halva ingredients. Carrageenan gels can forma connected and dense network structure causing the food ingredients place next to each other in a compact structure causing an increase in the fracturability of the food product (Löfgren et al., 2006). 


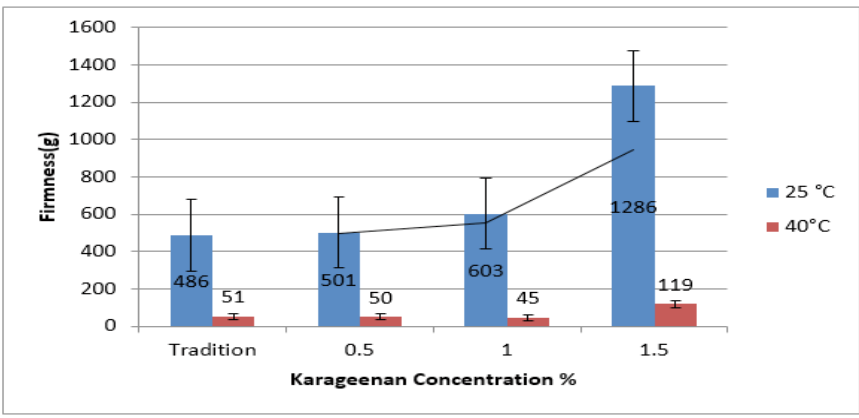

(a)

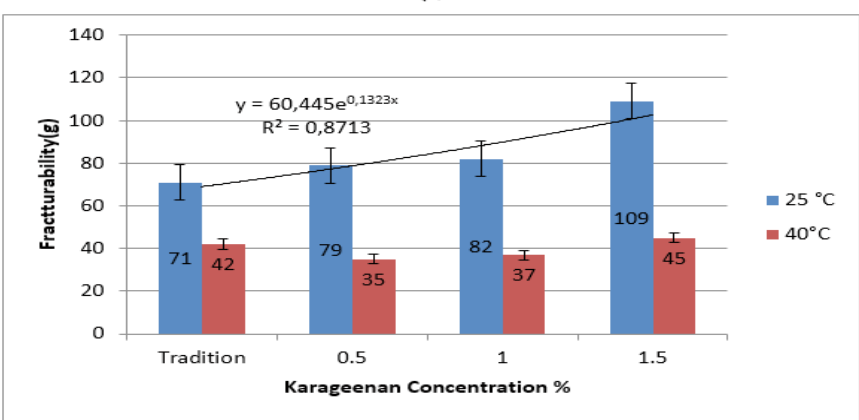

(b)

Figure 2: The effect of carrageenan gum concentration and storage temperature on the firmness (a) and fracturability (b) of halva Gazi

\subsection{THE EFFECT OF XANTHAN GUM ON FIRM- NESS AND FRACTURABILITY OF HALVA GAZI}

The firmness of halva Gazi was significantly affected $(p<0.05)$ by using different levels of xanthan gum, storage temperature and their interaction effect as represented in Fig. 3 a.

The samples containing $0.5 \%$ and $1 \%$ xanthan gum showed a softer texture in comparison to the control one. There was no considerable difference between the firmness of the halva containing $0.5 \%$ and $1 \%$ xanthan gum at $40{ }^{\circ} \mathrm{C}$. Adding $1.5 \%$ xanthan gum showed the preservative effect on the stored halva firmness at $40^{\circ} \mathrm{C}$; however, the texture of this sample was very firm and undesirable at ambient temperature. An increase in the xanthan gum levels up to $1 \%$ decreased the firmness of texture because of weakening the structure of the gel network by absorbing a higher amount of water. During the heating process, it prevented from high loss in the moisture content of the Halva producing the sample with a soft texture.

Movahed et al. (2014) evaluate the texture of the toast containing potato flour $(5,10 \& 15 \%)$ and xanthan hydrocolloid $(0.5 \& 1 \%)$ with wheat flour. The obtained results showed that the potato flour and xanthan gum softened the texture and prevented from the staling of toast after storage for 24,48 and $72 \mathrm{~h}$. Khalilian et al. (2011) used different levels of xanthan gum and pectin in the formulation of cantaloupe puree-based fruit pastel. It was reported that the use of xanthan in the formulation decreased the firmness of the surface of the sample. By adding the gums, the organoleptic properties of the cantaloupe pastel such as color intensity, texture firmness, and adhesiveness of surface texture were also changed. Comparing the consistency and serum reduction of ketchup containing different gums (guar, sodium alginate, acacia, xanthan, pectin, and carboxymethyl cellulose) revealed that the guar and xanthan gums produced the ketchup with the highest consistency at 0 to $50{ }^{\circ} \mathrm{C}$ (Gojral et al., 2003). Jahangir et al. (2013) reported that the using higher levels of flaxseed and xanthan gums in ketchup formulation could be effective in decreasing the amount of syneresis; as the samples containing xanthan gum showed no syneresis. Altunakar et al. (2006) found that hydrocolloids (xanthan gum and hydroxyl propyl methylcellulose) impact on the quality of chicken nugget by softening its texture.

Fig. 3b. shows the changes in the fracturability of halva Gazi influencing by the gum concentration, storage temperature and interaction effect $(p<0.05)$. The fracturability decreased $(p<0.05)$ as the higher levels of xanthan gum was used in the formulation of the halva. In the samples containing up to $1 \%$, the fracturability index 


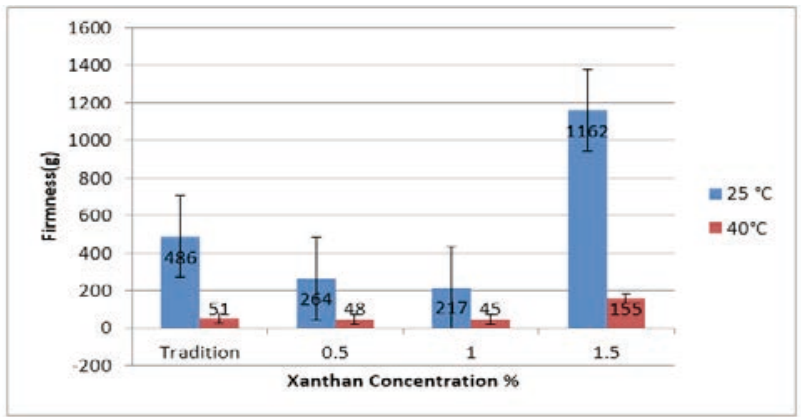

(a)

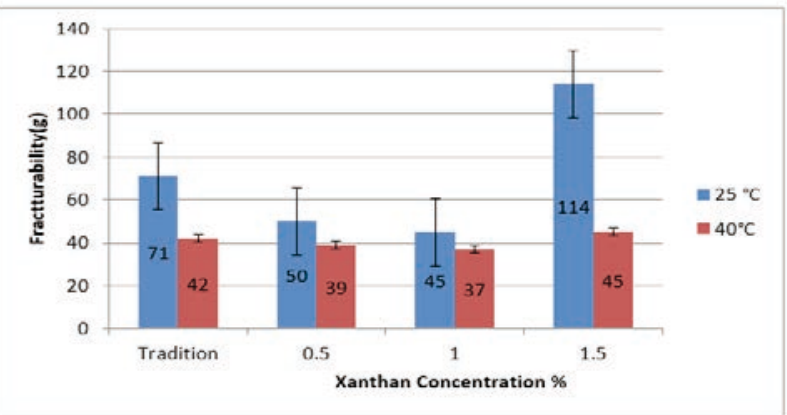

(b)

Figure 3: The firmness (a) and fracturability (b) of halva Gazi containing different levels of xanthan gum during storage at various temperature

decreased during storage at $25^{\circ} \mathrm{C}$. While a considerable increase in this factor was observed when the highest level of the gum (1.5\%) was added. During storage at $40{ }^{\circ} \mathrm{C}$, it was found that the fracturability of the sample having 0.5 and $1 \%$ xanthan gum was the same $(p>$ $0.05)$ which were lower than the fracturability of control and the. Comparing the effect of storage temperate on the fracturability of halva containing $1.5 \%$ gum determined that this gum was able to improve the texture of the sample at $40^{\circ} \mathrm{C}$, while its high firmness during storage at $25^{\circ} \mathrm{C}$ was unacceptable.

\subsection{THE EFFECT OF ALGINATE GUM ON FIRM- NESS AND FRACTURABILITY OF HALVA GAZI}

The effect of different concentrations of alginate gum on the firmness of the produced halva was significant $(p<0.05)$.In comparison to the control, the firmness of samples increased by using alginate gum (Fig. 4. a). The control and halva with $1.5 \%$ alginate gum had the least and the most firmness values, respectively. Storage at the higher temperature resulted in the lower firmness $(p<0.05)$. Unlike the stored samples at $40{ }^{\circ} \mathrm{C}$, the samples with $1.5 \%$ gum stored at room temperature showed a harder texture in comparison to the con- trol one. However, using 0.5 and $1 \%$ alginate brought the almost similar texture quality to the control during storage at both temperatures. Moreover, the interaction effect of temperature and gum concentrations increased the firmness of halva texture $(p<0.05)$. The effect of alginate on the texture of the halva can be related to the linear structure of the gel network and various chemical interactions such as the calcium bonds between the hydrocolloid and ingredients of the sample. The alginate gel does not melt at the boiling point due to the presence of the strong calcium bridges at the coupling points (Draget, 2000). Besides, the firmness of the alginate gel will increase by heating for a longer duration (Gureshi et al., 2009).

As shown in Fig. 4. b., different concentrations of alginate gum showed a considerable effect on alteration in the fracturability of the halva Gazi $(p<0.05)$ as, the samples containing higher levels of the gum showed almost higher fracturability index than the control. Storing the halva at different temperatures showed a considerable effect on this property $(p<0.05)$. There was no significant difference between the fracturability of the samples with 0.5 and $1 \%$ gum. During storage at $40{ }^{\circ} \mathrm{C}$, the texture of the Halva with $1.5 \%$ concentration of the alginate gum properly preserved; while, this showed very firm texture at ambient temperature that reduced the acceptance of the halva. The interaction ef- 


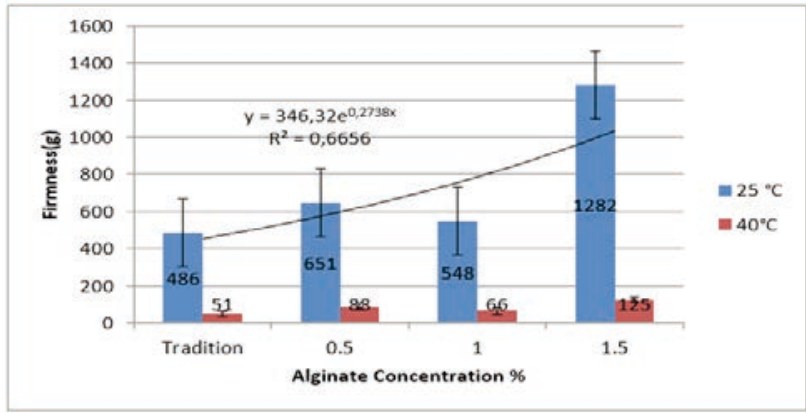

(a)

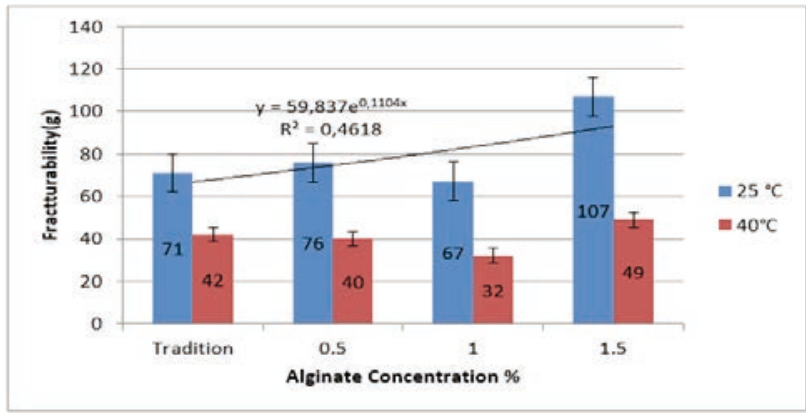

(b)

Figure 4: The firmness (a) and fracturability (b) of halva Gazi containing different levels of alginate gum during storage at various temperature

fect of temperature and different concentrations of alginate gum on the halva texture fracturability showed a reducing effect on this index $(p<0.05)$.

\subsection{THE EFFECT ON USING THE BLENDS OF DIFFERENT GUMS ON THE TEXTURE OF THE HALVA GAZI}

It was observed that using different blends of the gums results in producing the halva with softer texture $(p<0.05)$ in comparison to the control sample (Fig. 5. a).At $25^{\circ} \mathrm{C}$, the halva containing carrageenan-alginate gums and blends carrageenan-xanthan showed the lowest and the highest firmness. At $40{ }^{\circ} \mathrm{C}$, the halva containing carrageenan-alginate gums blend showed the softest texture following by the samples with carrageenan-xanthan and xanthan-alginate blends. This property was also affected by the storage condition $(p<0.05)$; as the firmness of halva Gazi decreased during storage at a higher temperature. The effect of the temperature was more noticeable in the firmness of the sample containing carrageenan- xanthan gum blend. Among the gumcontained samples, the halva with the xanthan-alginate gum blend had the firmer and the more heat-stable texture. In general, the blended gum-contained samples caused softening the texture at ambient temperature and higher temperatures. In addition, the use of blends containing xanthan gum showed high effectiveness in the preservation of the texture comparison to the control samples.

Omidbakhsh et al. (2013) investigated the effect of simultaneous use of modified starch and xanthan gum on stability, organoleptic and rheological properties of tomato sauce. It was found that at lower concentrations of xanthan gum, the addition of starch preserved thestability, rheological and organoleptic properties of the sample. Formulation of low-fat meatballs with guar and carrageenan gums decreased the hardness of the sample (Ulu, 2006).

As shown in Fig. 5b, the effects of gum blend and storage temperatures on fracturability were significant $(p<0.05)$. The carrageenan-xanthan blend gives halva more tender and more brittle texture than the other ones. The fracturability of the samples decreased at a higher temperature. Various studies have shown that the combination of two or more gums improved the texture of the food products. The simultaneous use of several gums resulted in better synergistic effects (Philips et al, 2000). Dehdashtiha et al. (2015) studied the impact of the addition of xanthan and guar gums on the textural properties of hamburger. The results showed that the use of the gum blend increased the softness and also improved its organoleptic properties. 


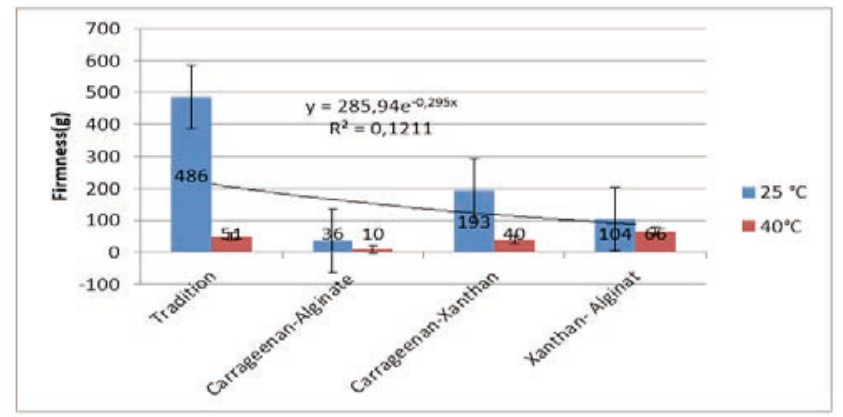

(a)

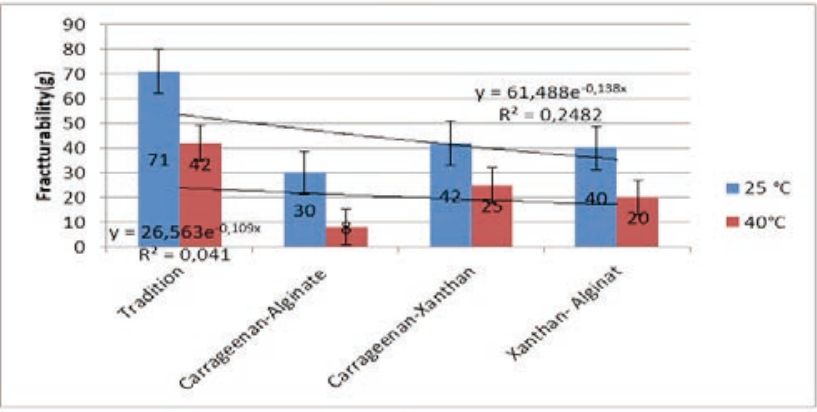

(b)

Figure 5: The effect of gum blend and storage temperature on the firmness (a) and fracturability (b) of halva Gazi

\section{CONCLUSION}

Halva Gazi is one of the traditional desserts with a high nutritional value which is produced in Iran. This product uses as a substitute for popular high-calorie foods such as breakfast chocolates and other fatty desserts. In this study, different levels of gums including xanthan, carrageenan, alginate gums and their blends were used to improve the texture of the halva Gazi during storage at $25^{\circ} \mathrm{C}$ and $40{ }^{\circ} \mathrm{C}$. The products containing gum blend and also xanthan up to $1 \%$ concentration produced an appropriate texture. However, the use of alginate and carrageenan gums increased the firmness of the halva in comparison to the control. The samples containing 0.5 and $1 \%$ of alginate and xanthan as well as xanthan-alginate blend and xanthan-carrageenan blend had the best texture properties during storage at $40^{\circ} \mathrm{C}$. These samples showed the most desirable softness at room temperature and the appropriate texture stability at $40{ }^{\circ} \mathrm{C}$.

\section{REFERENCES}

Altunakar, B., Sahin, S., \& Sumnu, G. (2006). Effects of hydrocolloids on apparent viscosity of batters and quality of chicken nuggets. Journal of Chemical Engineering Communications, 193(6), 675-682. https://doi. org/10.1080/00986440500194069
Bourn, M. (2009). Texture in solid and semisolid foods. Food Engineering, 2, 224.

Dehdashtiha, M. Hosseini, S. (2015). Effect of guar and xanthan gums on physicochemical and sensory properties of hamburgers. Journal of Food Science and Technology, 13(60).

Draget, K. (2001). Effect of molecular weight and elastic segment flexibility on syneresis in ca-alginate gels. Food Hydrocolloids, 15(4-6), 485-490. https://doi.org/10.1016/S0268005X(01)00046-7

Falah, Z. and Moatamedzadegan A. (1993). The role of film and food coatings in food safety. Second National Conference on Food Chain Optimization, Distribution and Consumption. (In Persian with English abstract)

Georgians A. Shahidi S. A. and Ghorbani a. (2014). Investigation of the effect of gum coating and osmotic dehydration on oil uptake during deep frying of salmon fillets. First National Conference on Development of a Comprehensive Strategic Quality in Food Health. (In Persian with English abstract)

Gujral, H. Brar,S. (2003). Effect of hydrocolloids on the dehydration kinetics, color and texture of mango leather. International Journal of Food Properties, 6(2), 269-279. https:// doi.org/10.1081/JFP-120017846

Jahangir, D. (2013). The effect of replacing xanthan with native basil gum on the physicochemical properties of ketchup sauce. Third National Conference on Food Security. (In Persian with English abstract)

Kihani, V. Mortazavi S. A., Karimi M., Karagian H. and Sheikholeslami Z. (2011). Investigation of the effect of ultrasound on emulsifying and foaming properties of edible extract of chubak compared to tween 80. National Congress of Mod- 
ern Agricultural Science and Technologies. (In Persian with English abstract)

Khalilian, S. and Martyr F. (2011). Investigation of tissue parameters of cantaloupe pastel as a function of different concentrations of pectin and xanthan using response surface methodology. First National Conference on Melon Production and Processing. (In Persian with English abstract)

Lofgren E. (2006). An experimental investigation of texture evolution during continous cooling. Journal of Volcanology and Geothermal Research, 154(1-2), 74-88. https://doi. org/10.1016/j.jvolgeores.2005.09.020

Movahed, S., and Mohseni G. (2014). Evaluation of application of xanthan gum and potato flour on rheological properties of toast and toast. Journal of Modern Food Technology, 25, 45-50. (In Persian with English abstract)

Nussinivitch A. (1997). Hydrocolloid applications, gum technology in food and other industries. London: Blackie Academic Press \& Professional. https://doi.org/10.1007/978-1-46156385-3

Omidbakhsh, E. Nayebzade K. (2013). Effects of combined modified starch and xanthan gum on the stability and rheological and sensory characteristies of tomato sauce. Iranian
Journal of Nutrition Sciences and Food technology, 8(1), 145158.

Qureshi, M. Ghanbarzadeh, B. Ghiasi, B. (2009). The effect of using the guar and carrageenan hydrocolloids on physical and sensory properties of Barbari bread. Journal of Food Science and Nutrition, Eighth Year (2).

Phillips, G. O. \& Williams, P. A. (2000). Handbook of hydrocolloids. CRC Press. USA. 473pp.

Szczesniak, A. (2002). Texture is a sensory property. Food Quality and Preference, 13(4), 215-225. https://doi.org/10.1016/ S0950-3293(01)00039-8

Takahishi, T. Hayakava, F. (2009). Relations among mechanical properties, human bite Parameters, and ease of chewing of solid foods with various textures. Journal of food engineering, 95(3), 400-409. https://doi.org/10.1016/j. jfoodeng.2009.05.023

Ulu, H. (2006). Effects of carrageenam and guar gum on the cooking and textual properties of low fat meatballs. Journal of Food Chemistry, 95, 600/605. https://doi.org/10.1016/j. foodchem.2005.01.039 